\title{
A Study on Problems Related to Work Life Balance among Women Employees in Information Technology Sector, Chennai
}

\author{
Deivasigamani J., ${ }^{1, *}$ Dr. Shankar ${ }^{2}$ \\ ${ }^{1}$ Phd Scholar,VIT University \\ Chennai ,India \\ ${ }^{2}$ Associate Professor,VIT University \\ Chennai,India \\ *Corresponding author's email: Jdeivasigamani [AT] yahoo.com
}

\begin{abstract}
As globalization has turn out to be the norm of the day, issues like these seem to have taken a back seat for quite a while. Work life "imbalance" has over the time attracted apprehension because of the over increasing troubles related to worker health declining levels of efficiency and productivity at the employee level, and boredom at work place. The difference also has a off putting impact in the personal life of working people some of which has developed to be social hazards like infertility due to high stress levels, growing number of divorces, beginning of nuclear families. Professional of the present day appears to be more involved in work that gives them bigger elasticity at work. Working community has diverse needs at different stages of their life. As a result, people strive for balance in their working hours and their personal commitments. Work life balance has now become a sensitive issue because it offers obvious benefits to organizations and its employees. Organizations can now focus on grooming their employees who these days are not merely regarded as work but considered as the human capital of the organization. This can go to a large extent help in retaining employee which may also be seen as an important driving force.
\end{abstract}

\section{WOMEN AND WORK}

Sujatha Mellacheruv (2008) in her study states that women as a part of the workforce and gaining recognition and choosing challenging careers. As a result they face a variety of pressures at home as well as at work place. Home related pressures are high in case of women who needed to take care of either younger children or elderly family members back home. On the other hand, women with grown up children and who enjoy support from the family members have less pressures. To deal with home related pressures these women adapt a variety of coping strategies. Working women in India are faced with lot more challenges than their counterparts in the other parts of the world. In India men do not share on most of the household chores, it is women who have to cook, clean the house, do the dishes, wash clothes, get their children ready for school etc. Men just took care of few chores that are to be dealt outside the house. So the major burden of running the family is on the shoulders of women. It was alright for women to handle all the chores as long as they were homemakers. Now with their increasing need for getting some income for the family, they have to work all the more harder. They have to take up a 9 to 5 job plus handle all the household chores that they handled as a homemaker. Men's role has not changed much. Women have started sleeping lesser than before because only when they wake up early they can cook for the family, get themselves ready for the job, get their children ready for the schools, so on an average, women lost 2 hours of sleep per day and up to 14 hours sleep per week. If they happened to work in a highly pressurized environment, then they will bring home their work and that cuts few more hours of sleep. It is not just about the reduced sleep, but such a lifestyle builds stress. This stress is passed on to the family and frustration level builds up in the family. They have to handle harassment's at their work place, sometimes just over look things to ensure that their job is not jeopardized in anyway. Many Indian families are still living as joint families along with the parents and in-laws. This adds to their stress further because they have to please all the family members of her husband. Listen to their complaints that they make against her and turn deaf ears towards them and so on. Overall, majority of women in India look towards or live in the hope that things will change. Some of us have given up that hope and learnt to accept that nothing can be done about it. India has a long way to go before our women will be able to live their lives to the full.

\section{WOMEN IN INFORMATION TECHNOLOGY SECTOR}

The technology revolution is changing the gender calculus in India, one of the world's most traditional societies. Women find new independence. Women play a larger part in the expansion of software market in India and they constitute 45 
percent of the high tech work force. Women account for 50 percent in the engineering colleges as well as in the software training sectors. In the organizational hierarchy, more women have occupied the responsible and high-profile positions but a few have climbed all the way up. The number of women executives has multiplied in the last few years. Though Information Technology sectors has offered equal employment opportunities to the gender groups differences are noticed in the types of activity that men and women software professionals showed that a high concentration of men exists in export software firms, while women are present in higher proportion in domestic low end and Information Technology enabled services. This implies that at the entry level itself there is a marked gender differential in access to employment in this sector. In addition, during personal discussions both men and women indicated that due to domestic responsibilities a few women were unable to cope with the work intensity in high-end activities. It is observed that the Information Technology industry's attitude is one of benign statistical discrimination of women by accepting the gender constraints of women. Sectors wherein women's work participation is relatively high, there is a provision for crèches. Hence if the Information Technology policy claims of a gender-neutral sector are to come true it is imperative to first address the practical needs of women professionals.

\section{WORK LIFE BALANCE}

Work life balance is the degree to which individuals are able to satisfy their important personal needs while employed by the firm. Companies interested in enhancing employees will generally try to instill in employees feelings of security, equity, pride, family democracy, ownership, responsibility and flexibility. They try to treat employees in fair ad supportive manner, open communication channels at all levels, offers employees opportunities to participate in decisions affecting them and empower them to carry through on assignments. Igbaria, et.al.(1991) found that employees whose work setting was compatible with their career orientation reported higher levels of work and life balance than employees whose career orientation did not match attributes of their work setting. However managing activities at home is the domain of the employees. Work life balance does not mean an equal balance. Burke.R.J, (2002) found out that both women and men prefer working in organisations that support work-life balance. Men appeared to benefit more than women. When work does not permit women to take care of their family, they feel unhappy, disappointed and frustrated. They draw tight boundaries between work and family and they do not like one crossing the other. The best work life balance is different for each of us because we all have different priorities and different lives. The right balance between work and the rest of our lies varies from person to person and the policies and practices an employer can introduce will depend very much upon the organizational setting in which employees work. This encourages the employers to adopt working practices which are consistent with business goals at the same time as improving their employees Work life balance.

\section{STATEMENT OF THE PROBLEM}

Women play a vital role in economic development of the country and their contribution is nothing short of their male counterparts. However there are still several issues and problems that women face today. Sometimes, they are not treated equally in their workplace and are considered as inferior to their male co-workers. In some cases they do not get the same benefits as that of a male employee. The major issues and problems that women face in their work places includes unequal pay, security, sexual harassment, lack of proper family support, deficient maternity leave, etc. Women in India have come a long way after independence. From just a skilled homemaker, women today have acquired skills and capabilities of not just being a homemaker but being at par with their male counterparts. This is the new generation of women, who wants to pursue their dream career. But this life is not a bed of roses for all. Working women face lots of problems in their work place. And that too for women employees in Information Technology sector face numerous physical and psychological and occupational challenges. Based on this focus the researcher conducted the study on the problems related work life balance by the women in Information Technology sector at Chennai.

\section{SIGNIFICANCE OF THE STUDY}

In recent times, women are fast pervading almost all traditionally male-dominated professions and performing effectively. Mostly career oriented women are likely to get stressed while striking a balance between multiple roles that they are required to do which result into occupational stress. Occupational stress in case of women results from adverse working conditions, dysfunctional internal and external attitudes that engulf the individual's coping resources and manifests in acute cognitive, emotional, behavioral or physical problems. Stress at work can cause major damage to one's health and overall lifestyle and it is an area that should not be ignored. In spite of knowing the above fact, the researcher thought identifying the problems of women employees related to work life balance in Information Technology sector is the need of hour. 


\section{OBJECTIVES}

- To know the demographic details of the women employees in Information Technology sector at Chennai.

- To study the various problems related to Work Life Balance of women employees in Information Technology sector at Chennai.

- To suggest suitable measures to overcome the problems related to Work Life Balance of women Employees in Information Technology sector at Chennai.

\section{RESEARCH METHODOLOGY}

The researcher adopted Descriptive Research Design to this study. Since the Design is one in which the primary goal is to assess a sample at one specific point in time and to describe a particular phenomenon. It was the most appropriate design to use. More over the study aims to deal with the various problems related to work life balance of Women employees in Information Technology sector. Thus the Descriptive Research Design is the most suitable Research Design to this study. The researcher conducted pilot study to find out the feasibility of the study and also to know the availability of the respondents. The researcher adopted Focus Group Discussion as a qualitative method for the data collection. The discussion was designed to gather information from the women employees in Information Technology sector with regard to the following outcomes:

- To understand the opinion of the women employees about the status of working women.

- To know how the employees perceive the work environment.

- To make out employees views on Superior-Subordinate relationship.

- To understand the employees views on interpersonal relationship in the office.

- To reveal the work related issues that the women employees are facing in the work place.

- To know the Psychological problems that the women employees face because of the work.

\section{RESULTS AND DISCUSSION}

In this research, Majority of the respondents were below 30 years and they have done professional degree. In this research, majority of the respondents are married and they were getting income in the range of Rs.20,000 - 40,000/-. Majority of them have 3-6 Years of experience. Vast majority of the respondents are working 5 days in a week and they spend nearly an hour for traveling. Vast majority of the respondents work in general shift. In this research, most of the respondents said financial independence is the motivational factor. The researcher conducted two focus group discussions involving various women employees from Information Technology sector. The outcomes of the focus group discussion are as follows;

\section{Opinion on the status of working women} follows;

Every participant was eager to state their views. The employees gave number of valid points. They are as

Women are given equal importance and rights these days in the society. It is necessary for a woman to be independent these days. Women are given the status of work after long years of struggle. But the struggle is not yet completed as her status is socially not equal to men. So the struggle is still on in the work place, house, and society. Majority of the working women are not supported by family or husband. Women undergo pressure on both sides which eventually becomes stress on them. They can be given more support and confidence from family and social background. It is necessary that women work these days and earn a status equal to that as men and be given the necessary rights, freedom to take decisions and challenges as she is no less than men these days. For financial conditions and living standards these days it is very important that women work and support the family from her side. These days it is well aloud said that women are given equal importance to men and share equal rights everywhere as men do. But in 70-80\% of the situations it turns out to be only a mere statement. It doesn't seem to work practically as women are treated Women everywhere. In the sense, they are treated very unfair in every place.

Working women holds the same status as they had a decade back. Working women can come to know about a variety of things each day. They can become bolder enough to face any situation. But at the same side there are many disadvantages for them. Each day is a battle for them. Status of working women is a very tough life and my point of view women don't have enough time to spend for themselves. Always bound by family work, office work, eventually they fail to concentrate on themselves. In the modern days, women want to earn equally as men and as the cost of living and standard of living has risen tremendously these days, it is good for a women to be financial independent and sound to lead a better life. History says, women are given equal rights as that of men and given the freedom of speech. But after all 
a women is a women when she steps out of her house or in her house and is never given such importance or consideration. The same is with her Work status. She works all day night but is not benefited in any way, no credits or recognitions achieved. Most of the women said the negative status of working women. An employee stated though women have empowered to a much greater aspect but the tag "After all a Women" never change.

\section{Opinion about work environment}

Need to be friendly, pleasant, co-operative, not dominating by the other gender, healthy, happy, Safe environment and fun-filled. Work environment is not comfortable in all cases. Comfortability should be improved in lot of aspects. Few companies provide a healthy environment for women and this encourages working women. The count of this can be increased. Women must be given the freedom to work and take decisions on their choice. When a woman can run a family, the same woman has the capacity to run an organization and take up wise decisions and make it profitable. All that she asks for is a chance and the freedom to establish her tasks and goals. Except few industries, females are either not let to come up to the top hierarchy or they are not considered worthy enough of the work which guys do. Each one's perspective varies in a work environment.

The way they treat man and women varies. Women highly need to be very cautious at each and every moment about her. Majority of the work place is much stressed, monotonous. It should be convenient timings for women considering her health aspects and providing cab facilities. In the olden days, women are subjected only to household works, which is not the case these days. So if the environment is encouraging, then more women will step out of their doors and face the outside world and take up challenges. An equal status, freedom, respect, regard given to women as men for her to take up challenges and work peacefully to get the best out of herself. Nearly half of the women employees said that the work environment is male dominated and the women are not considered on par to the men.

\section{Relationship between Superior and Subordinate}

Sole responsibility of the superior to guide every subordinate and bring them under the right track and ensure team work and co-operation exists among the team members for the individual's success and the team success. It is better if there is no relationship most of the time. But at the time of help, it is very essential for them to transfer their inputs and knowledge so that the sub ordinate can perform their task well. It is better to avoid the thought of superior subordinate and exchange ideas mutually to benefit each other. It should lead a healthy relationship, not much sharing of personal matters. Preferably on a good path as superiors tend to listen to their subordinates. But in public sector subordinate are still treated like slaves. Few superiors show attitude while a few are friendly and sweet. That should not be the case. They should be free enough to be approached incase the subordinates face any sort of issues in their work or in their work environment or with their colleagues. Superior should be like a role model for the sub ordinates and provide them with the maximum help and guidance from their side. More respondents said they want to have a smooth relationship with their superiors. They want their superiors to guide them properly in their work.

\section{Views on the Interpersonal Relationship}

Better to maintain a distance from everyone and stop with office related talks alone. There is not any requirement for personal relationships in work environment. It would be good if relationships are professional and healthy for each other. Colleagues are friendly and helpful in work environment. Better not to share our personal problems with people around and mainly avoid gossips about people. Maintain a healthy relationship which starts at 9 in the morning and ends at 6 in the evening. It's an outspoken environment these days, where people built up a healthy relationship amongst each other. Generally it can be avoided with personal talks, gossips can be avoided. It's better that we concentrate more on work and just for relaxation talk to people freely. It's good that we don't comment about someone to others to avoid problems and stay peaceful. Helping each other in times of need. Healthy relationship that would end within office suffices. It is necessary to have people around to share our thoughts and have fun. 6 out of 10 respondents said to avoid sharing too personal things with the colleagues and at the same time we have to maintain decent relationship with the colleagues. One respondent stated "According to me, personal sharing can be avoided with everyone. Work is more important, so it's better to concentrate on the same and leave for the day".

\section{Occupational Challenges faced}

Deadlines are the major criteria cause of which we are stressed and pressurized to work on weekends, extended hours. Asking to work for 7 days particularly on Sunday. Work is not very interesting,. But there is not much stress on individuals. Most tasks are group assigned and this helpful in learning new things that work demands. Not given sufficient time to complete the work, sometimes asked to work on weekends as well, too much of pressure to finish a work within the time. Work related issues arise when your opinion can't be accepted by others. Or when you don't accept 
to whatever they ask for. Stressful work which in turn leads to a lot of health issues like hair fall, eyesight problem, headache etc. Memos, escalations and less time to learn. All these factors pose major threat, lack of encouragement and build less confidence within the person, finally not able to achieve what they wanted to. The response from all the respondents were same that they are very stressed and pressured because of work related issues. An employee stated that "These issues are nothing but pressure cookers in which we are cooked up".

\section{Psychological problems faced}

Women employees face many psychological problems such as Mental Stress, Anger, Depression, Hyper tension, Mental torture Headache, Obesity, Back pain, No proper sleep, Neck pain, Less patience, Frustration, Irritation, Lack of confidence. They said they become a machine because of the work stress.

\section{Summary of Focus Group Discussion}

All the respondents were active throughout the session and shared maximum points with the researcher. They had more negative points to share because they face really lot of challenges in their work place. In every aspect, it may be interpersonal relationship, Superior-Subordinate relationship, mental health and work environment, in everything they have some issues and they are waiting for some immediate actions to solve those issues They accept that being a women working in Information Technology sector is really a challenging task and they expect cooperation from other gender, superiors, and family to keep their job done peacefully. It is very alarming from the discussion that specifically they face lot of psychological challenges and proper care should be given to rectify the issues.

\section{DISCUSSION}

The researcher through this research wished to study the problems related to Work Life balance of women employees in Information Technology sector. The occupational stress is the by-product of complex industrial organization. Role stress may occur because of conflict between work and non-work activities (O'Driscall et al. 1992). It is very clear from the results that nowadays young girls are very aspirant and they want to go to a well settled job as soon as they finish their studies. Young girls are very clear in choosing their degree, because they know very well that doing professional degree will always helpful for them to begin their career in Information Technology sector. Nowadays young girls want to earn more and want to be economically independent before they get married.

Study done by Ofreneo, et. al., (2007), the odd working hours against the biological clock makes women employees suffer from a number of ailments. The cumulative effect of odd working hours and stressful working environment leads to voice problem (dry, itchy throat, hoarseness, cleaning of throat, cracking of voice, cough, cold, etc.), eye strain (itchiness, smarting, redness, tearing, dryness and pain due to lighting situations and uninterrupted use of computers for long hours), hearing problem (ear pain, ringing in ear), pain in neck, shoulder, back, wrist and mental and psychological stress. In this study also more number of respondents stated that sometimes they have to work hard and vigorously to accomplish the targets in the stipulated time. Ganster (1995) studied that Supervisor support has also been shown to be related to work-family conflict Employees who have supportive supervisors are more likely to perceive their organization as family supportive and perceive they have more control over work and family, which in turn are related to lower levels of work-family conflict. Whereas a lack of work-related social support (including low supervisor support), increased work-family conflict, which, in turn, resulted in increased psychosomatic symptoms (anxiety, depression, somatic complaints) and also the result depicts that, more than one third of the respondents sometimes have constant work pressure due to heavy work load.

In the study done by Kumudha, J. Jancy Rani (2012) majority t of the respondents complaint about feel angry and irritable because of work pressure in information Technology Sector. It reflects in this study also. Thus the researcher is concluding that women working in information Technology sector are suffering from numerous challenges and the existing researches are also proving the same. Hence, necessary steps should be taken to sort out the issue at the right time.

\section{SUGGESTIONS}

After carrying out vigorous analysis of the response given by the women employees, here the researcher wants to give suggestion on particular areas which are involved in controlling the issues faced by women employees in Information Technology sector. The following are the few suggestive measures given by the researcher to overcome the problems faced by women employees in Information Technology sector. 
- Organizations should take some proactive action before actually indulging their women employee in work likewise arranging some workshop or training on removing stress.

- Further organization are require to change their mindset about sex discrimination and should try to increase their trust on women in the way of giving empowerment, participation in management, leadership, job enrichment, role clarity etc.

- Organization should be resilient in formulating policies regarding leaves, work load, timings etc. up to some feasible extent.

- Organization should organize some special workshops for their women employees and their families for increasing emotional and domestic support from home/society in the way of telling importance of her work for their family and for organization.

- Entertainment, conducting cultural programs within organization can be carried out so that the stress level of the women employees could be reduced.

- Friendly, informal working atmosphere is one of the factors which help the individuals to cope up with stress. So organization should create a healthy, friendly working atmosphere

- Women should also indulge themselves in some meditative exercise for relieving stress from mind as family and career is a part and parcel of life. It depends upon women how she tackles the situations.

- Women employees' complaints on sexual harassment should be solved immediately by the management. .

- The relationship between Superior-Subordinate should be streamlined.

- The employers should organize proper grievance and stress management sessions in which women employees can discuss their problems. Moreover a proper grievance redressal cell can help in solving many problems.

\section{Role of Employer}

The research finding shows more number of employees are working for financial independence, the employers should design the pay packages according to the volume of work and retain the employees for longer period of time. The employers should organize proper grievance and stress management sessions in which women employees can discuss their problems. The management should create a worker friendly environment so the employees will really be happy to do the work. This research reveals that more number of respondents spend nearly one hour for traveling, the management should provide them good cab facility, so that it will be helpful for the women employees who works in the night shift. As far as the promotion aspect is concerned, the employers shall design the jobs in such a way that there are more challenges and opportunities for the women employees and more growth prospects in future. Equality should also be given importance. Many women have faced the problem of being women and unequal treatment. The employers shall look into this matter and organize competitions which will definitely boost up women employees' spirits and inculcate sense of achievement. On security front, the employers shall arrange for proper security and a code of ethics should be circulated and strict punishments should be given to the offenders.

\section{Role of Employee}

The women employees should not hesitate to complaint about their issues to higher authorities or women employee grievance cell. Whatever may be the issue like violence, sexual harassment, or bullying, ill treatment by other sex, they have to immediately bring this issue to limelight. Even in our research, most of the respondents are not aware of the sexual assault faced by the colleagues and also whether they get justice for that or not. They must be bold enough to face the issue, from the research it is evident that their mental health is also getting affected to a greater extent. So, the employees should involve themselves in recreational activities to get rid of the work pressure.

\section{Role of Colleagues}

The Inter-Personal relationship with the colleagues should be strengthened. The employees must know their limits to behave with both the gender. At the same time they should get proper support from their colleagues in their job. They can be helpful to each other morally. And the colleagues should stand together if any discrimination or violence faced by their colleagues.

\section{Role of Government}

Government should have more concern regarding the women working in Information Technology sector. If the women employees face any serious problem inside or outside the working place, proper justice should be given to the victim and the offender should be punished. Government must always have a check in the working practices that prevails in the company and must ensure the safety and security of the women employees. 


\section{CONCLUSION}

This research outlines the various problems faced by women employees in Information Technology industry with special reference to Chennai. The research work reveals that most of the respondents are facing various physical and psychological problems due to their nature of work. It is an open truth that working women have to face problems just by virtue of their being women. The age old belief of male superiority over women creates several hurdles for women at their place of work. Working in Information Technology industry inevitably puts strains on women to greater extent as compared to men. Women in Information Technology industry suffer from physical discomfort, psychological problems and mental tension. Women employees are facing occupational challenges such as late working hours, long working hours at the desk, job related pressure, deadlines, being treated unfairly at work, lack of break timings during working hours and sexual assault. In spite of this there are certain other consequences of sedentary lifestyle such as anxiety, depression, , mental tension, sleep disturbance, irritability, boredom faced because of during monotonous work and problem of balancing work at home and office are some of the mental tensions that the women employees are facing in their job. These findings can be useful for to help working women reduce problems related to occupational and psychological challenges by giving them better care in the work place. There is a great need for research on working women, as they are in the position to balance both work and personal life.

\section{REFERENCES}

- Burke, R. J. (2002). "Organizational values, job experiences and satisfaction among managerial and professional women and men: Advantage men?” Women in Management Review, Vol.17 (5), pp.5-6.

- Ganster, D. C., \& Schaubroeck, J. (1991). "Work and Stress and Employee Health. Journal of Management", Vol 17, pp 235-271.

- Igbaria, et.al., (1991) cited in Frone, M.R. and Rice, R.W., (1987) Work- Family conflict: The effect of job and family involvement, Journal of Occupational Personality, 8, 45-53.

- Kumudha.A, Jancy Rani.J,(2012) “An Empirical Study on Problems Faced By Women Employees in Information Technology Industry with Special Reference to Coimbatore City", International Journal of Management \& Information Technology, September Volume 1, No 3, pp. 99- 103.

- O'Dricriscall MP,Ugen DR,Hildesth K(1992), Time devoted to job and pff-Job activities,Inter role conflict and affective experiences.Journal of applied Psychology,76:42.

- Ofreneo, E. R., Ng, C. and Pasumbal, M.L (2007), "Voice for the Voice Workers: Addressing the IR Concerns in the Call Center/BPO Industry of Asia”. Indian Journal of Industrial Relations, 42 (4):534-557

- Sujatha Mellacheruvu,(2008) "A study on Home related pressures of working women" Pratibimba - The journal of IMIS, Volume-8, and issue: 1, Januray-June, Page21-28.

- http://www.thehindubusinessline.com/bline/ew/2005/09/05/stories/2005090500080100/html.

- http:// www.dataquest.com/ employer -survey - 2013/ html

- http://www.nasscom.in/The-2020-Challenge-Before-IT-BPO-56638,2013 